\title{
KOMPOSISI DAN POLA SEBARAN MAKROALGA DI PERAIRAN DESA MANTANG BARU, KABUPATEN BINTAN, KEPULAUAN RIAU
}

\author{
The Composition and Distribution Pattern of Macroalgae in Mantang Baru \\ Village Waters, Bintan Regency, Riau Islands
}

FENDI PRADANA, TRI APRIADI, ANI SURYANTI

Universitas Maritim Raja Ali Haji

Email: tri.apriadi@umrah.ac.id

\begin{abstract}
The objective of this study was to determine macroalgae composition, macroalgae distribution, and waters quality in Mantang Baru village, Bintan Regengy, Riau Islands. This research has done on March - May 2019. Sampling points were choosen by purposive sampling method. There were 3 stations based on the ecosystem; coral ecosystem, seagrass ecosystem, and area in front of mangrove ecosystem. Macroalgae were observed by line transect method. Transect was placed at each location for taking macroalgae as many as 3 lines of transect along $100 \mathrm{~m}$, the determination of the first plot was based on the first point of discovery of macroalgae drawn vertical to the coastline between lines $100 \mathrm{~m}$. The results showed that the highest composition in seagrass ecosystem was Chlorophyta (green algae) 59\%. Phaeophyta (brown algae) was the higest composition in coral ecoystem and area in front of mangrove ecosystem, with value $69 \%$ and $44 \%$ respectively. The distribution pattern of macroalgae in Mantang Baru Village waters on each station included a grouping category with a range of values between 1.87 to 3.46. Water quality parametres in Mantang Baru Village met the water quality standard, except nitrate and phosphate..
\end{abstract}

Keywords: Composition, Mantang, Macroalgae, Distribution Pattern

\begin{abstract}
Abstrak Penelitian ini bertujuan untuk mengetahui komposisi jenis makroalga, pola sebaran makroalga dan mengetahui kualitas perairan di pesisir Desa Mantang Baru Kabupaten Bintan, Kepulauan Riau. Stasiun pengambilan sampel ditentukan dengan metode purposive sampling. Terdapat 3 stasiun berdasarkan keberadaan ekosistem, yaitu ekosistem karang, ekosistem lamun, dan perairan berhadapan mangrove. Pengambilan sampel makroalga dilakukan pada setiap stasiun pengamatan menggunakan metode transek garis. Penempatan transek pada tiap lokasi untuk pengambilan makroalga sebanyak 3 garis transek sepanjang $100 \mathrm{~m}$, penetapan plot pertama dilakukan berdasarkan titik pertama kali ditemukannya makroalga yang ditarik tegak lurus terhadap garis pantai dengan jarak antar garis $100 \mathrm{~m}$. Hasil penelitian memberikan informasi bahwa divisi Chlorophyta (alga hijau) merupakan kelompok yang paling banyak dijumpai di ekosistem lamun (59\%), sedangkan di ekosistem karang dan daerah yang berhadapan dengan mangrove, komposisi tertinggi dari divisi Phaeophyta (alga coklat) dengan komposisi masingmasing 69\% dan 44\%. Pola sebaran pada jenis makroalga di perairan Desa Mantang Baru pada setiap stasiun termasuk kategori mengelompok dengan kisaran nilai 1,87-3,46. Parameter fisika dan kimia perairan di Desa Mantang Baru secara unum memenuhi baku mutu peruntukan biota, kecuali parameter nitrat dan fosfat.
\end{abstract}

Kata Kunci: komposisi jenis, Mantang, makroalga, pola sebaran 


\section{PENDAHULUAN}

Pulau-pulau yang terdapat di perairan Bintan, Kepulauan Riau, umumnya memiliki karakteristik perairan yang tenang sehingga kawasan tersebut mendukung untuk kehidupan berbagai jenis makroalga dan biota laut lainnya. Salah satu daerah yang memiliki potensi jenis makroalga dan biota lainnya, terutama di perairan pesisir Pulau Mantang, tepatnya di Desa Mantang Baru, Kabupaten Bintan. Penduduk Desa Mantang Baru melakukan kegiatan budidaya rumput laut (Eucheuma cottonii) sebagai usaha sampingan selain sebagai nelayan (Hambali et al., 2012), tetapi menurut masyarakat sekitar budidaya rumput laut sudah berhenti dikarenakan perairan yang mulai tidak sesuai untuk pertumbuhan jenis rumput laut tersebut. Pengaruh lain oleh faktor lingkungan yang dinamis dapat menjadi penyebab stres pada suatu jenis rumput laut yang mengakibatkan pertumbuhan terhambat dan dapat berlanjut kematian (Kadi, 2015).

Makroalga merupakan salah satu sumber daya hayati laut bernilai ekonomi, memiliki manfaat yang baik untuk manusia dan lingkungan sekitarnya. Manfaat makroalga bagi manusia adalah sebagai bahan makanan, bahan dasar kosmetik, dan bahan pembuatan obat. Makroalga bermanfaat bagi lingkungan sekitarnya karena dapat memproduksi zat-zat organik melalui proses fotosintesis yang bermanfaat bagi ekosistem laut (Rosdiana et al., 2017). Perairan pesisir Desa Mantang Baru memiliki sumberdaya rumput laut (makroalga) tetapi belum teridentifikasi jenis dan sebarannya. Penelitian ini bertujuan untuk mengetahui komposisi jenis makroalga, pola sebaran makroalga dan mengetahui kualitas perairan di pesisir Desa Mantang Baru Kabupaten Bintan, Kepulauan Riau.

\section{BAHAN DAN METODE Waktu dan Tempat}

Penelitian ini dilaksanakan pada bulan MaretMei 2019. Pengambilan sampel dilakukan di Perairan Desa Mantang Baru Kabupaten
Bintan, Kepulauan Riau. Identifikasi sampel makroalga dilakukan di Laboratorium Marine Biology Fakultas Ilmu Kelautan dan Perikanan Universitas Maritim Raja Ali Haji Tanjungpinang, sedangkan sampel nutrien dianalisis di Balai Perikanan Budidaya Laut Batam.

Stasiun pengambilan sampel ditentukan dengan metode purposive sampling. Stasiun ditentukan 3 ekosistem: karang, lamun, dan daerah berhadapan dengan mangrove. Stasiun 1 pada ekosistem terumbu karang, stasiun 2 pada ekosistem padang lamun, dan stasiun 3 berhadapan dengan ekosistem mangrove (Gambar 1).

\section{Metode Penelitian}

Pengambilan sampel makroalga dilakukan pada setiap stasiun pengamatan menggunakan metode line transect (transek garis) dengan teknik sampling kuadrat (Fachrul, 2007). Penempatan transek pada masing-masing lokasi untuk pengambilan makroalga sebanyak 3 garis transek sepanjang $100 \mathrm{~m}$ penetapan plot pertama dilakukan berdasarkan titik pertama kali ditemukannya makroalga yang ditarik tegak lurus terhadap garis pantai dengan jarak atar garis $100 \mathrm{~m}$ (Gambar 2). Jarak dari pertama kali ditemukannya makroalga ke plot pertama adalah $10 \mathrm{~m}$, sedangkan jarak dari plot pertama ke plot kedua dan seterusnya adalah $9 \mathrm{~m}$ dikarenakan jarak dari pertama kali ditemukannya makroalga dikurangi dengan luas transek. Sampel dihitung dan diambil pada surut terendah dengan ukuran transek kuadrat yang dipakai untuk pengambilan data yaitu 1x1m (Meriam et al., 2016).

Parameter fisika-kimia perairan yang diamati meliputi kedalaman, dan kecerahan (menggunakan secchi disc), kecepatan arus (current meter), suhu, $\mathrm{pH}$, dan $\mathrm{DO}$ diukur menggunakan multitester (APHA, 2012). Nitrat dan fosfat diukur secara spectrophotometric (APHA, 2012). 


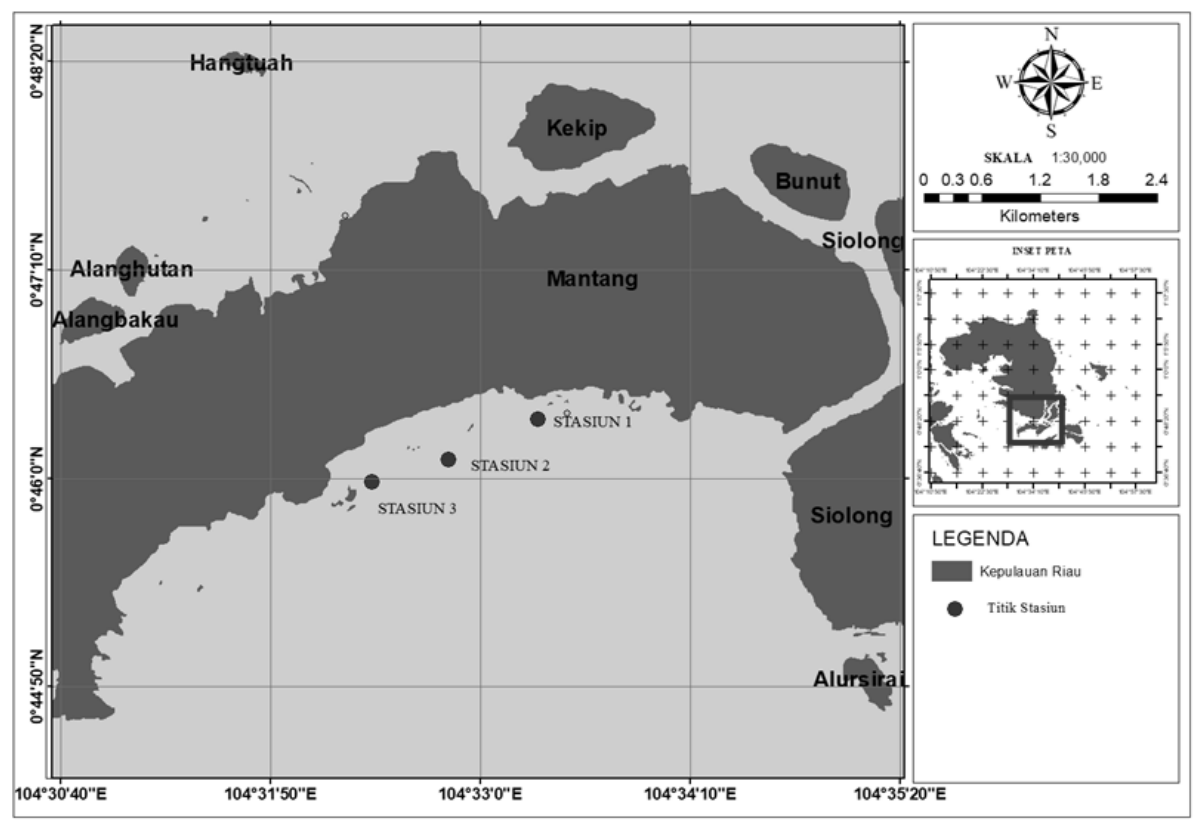

Gambar 1. Lokasi pengambilan sampel di perairan Desa Mantang Baru, Kabupaten Bintan

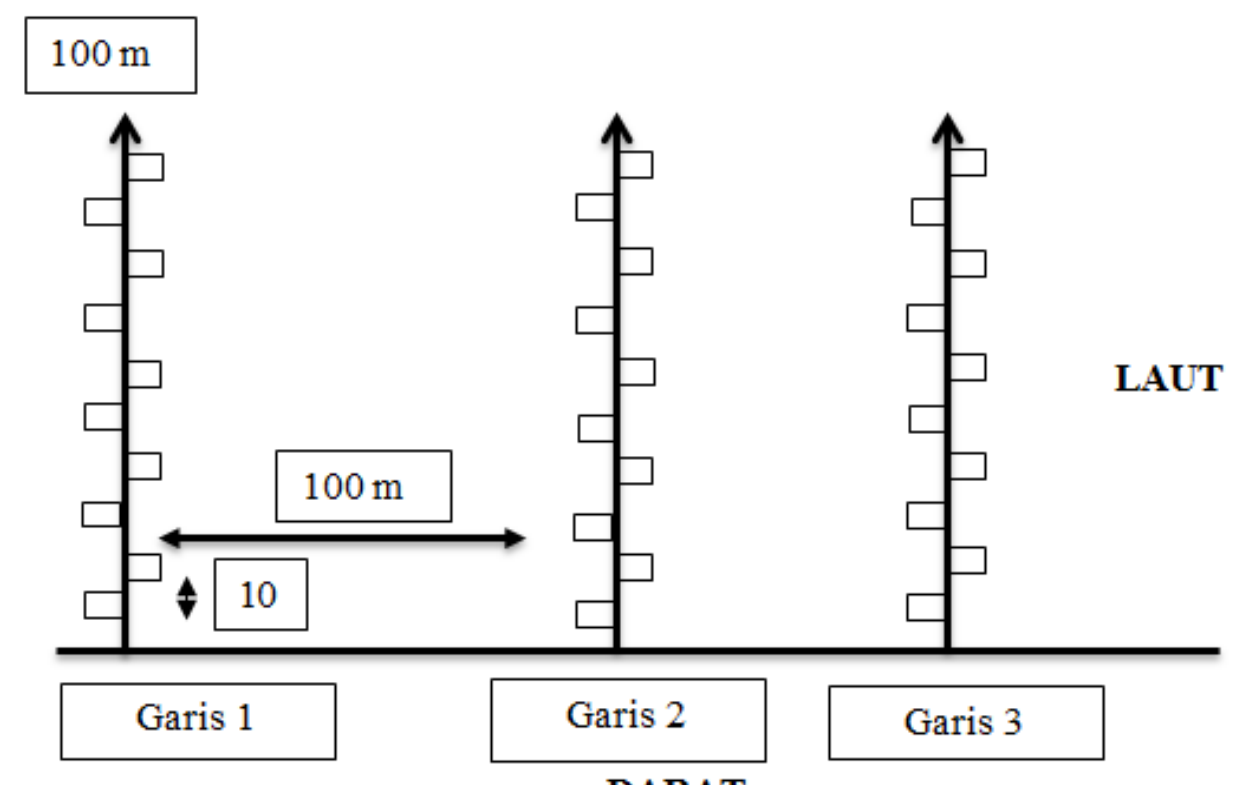

DARAT

Gambar 2. Teknik sampling dengan metode line transect pada setiap stasiun

\section{Analisis Data}

\section{Komposisi jenis makroalga}

Hasil pengamatan jenis-jenis makroalga yang ditemukan di perairan pesisir Desa Mantang Baru dihitung jumlah individu perjenis atau perspesies sehingga mendapatkan komposisi jenis dengan rumus (English et al., 1997).

Keterangan :
$\mathrm{Ki}=$ Komposisi jenis ke-i (\%);

$\mathrm{Ni}=$ Jumlah individu jenis ke-i (tegakan);

$\mathrm{N}=$ Jumlah total individu (tegakan)

\section{Kerapatan jenis makroalga}

Kerapatan masing - masing jenis pada setiap stasiun dihitung dengan menggunakan rumus (Fachrul, 2007) sebagai berikut :

$$
\mathrm{Ki}=\frac{\mathrm{ni}}{\mathrm{A}}
$$


Keterangan:

$\mathrm{Ki}=$ Kerapatan jenis ke-i

$\mathrm{ni}=$ jumlah seluruh tumbuhan

$A=$ jumlah seluruh sampling unit $\left(1 \mathrm{~m}^{2}\right)$

\section{Indeks Keanekaragaman}

Nilai keanekaragaman jenis biota perairan dihitung berdasarkan indeks shannon-Wienner (H') (Krebs, 2014) dengan rumus:

$$
\mathrm{H}^{\prime}=-\sum_{i=1}^{s}(p i)(\log p i)
$$

Keterangan :

$\mathrm{H}^{\prime}$ = Indeks keanekaragaman

$\mathrm{s}=$ Jumlah koloni setiap species

pi $=$ Jumlah koloni seluruh spesies

\section{Indeks keseragaman}

Keseragaman jenis dapat dihitung dengan menggunakan rumus Evennes (Krebs, 2014), yaitu:

Keterangan :

$$
\mathrm{E}=\frac{\mathrm{H}^{\prime}}{\mathrm{H} \max }
$$

$\mathrm{E} \quad=$ Indeks Keseragaman;

$\mathrm{H}^{\prime} \quad=$ Indeks Keanekaragaman;

$\operatorname{Hmax}=\log (\mathrm{S})$

\section{Indeks dominansi}

Untuk mengetahui dominansi jenis tertentu di perairan dapat digunakan indeks dominansi Simpson (Krebs, 2014)dengan rumus:

Keterangan:

$$
\mathrm{C}=\sum(p i)^{2}
$$

$$
\begin{array}{ll}
\mathrm{C} & =\text { Indeks dominasi Simpson } \\
\mathrm{pi} & =\text { proporsi spesies ke-i }(\mathrm{ni} / \mathrm{N})
\end{array}
$$

\section{Pola sebaran}

Pola sebaran makroalga dihitung berdasarkan ersamaan pola sebaran Morisita (Id) menurut Brower et al. (1990).

Keterangan :

$$
\mathrm{Id}=\mathrm{n} \frac{\sum \mathrm{x}^{2}-\mathrm{N}}{\mathrm{N}(\mathrm{N}-1)}
$$

Id = Indeks dispersi morisita;

$\mathrm{n}=$ Jumlah plot pengambilan contoh;

$\mathrm{N}=$ Jumlah individu total dalam plot;

$\mathrm{x}^{2}=$ Jumlah individu pada setiap plot

kriteria pola sebaran (Id) yaitu $\mathrm{Id}=1,0$

pola penyebaran acak, Id $<1,0$ pola penyebaran merata, Id $>1,0$ pola penyebaran mengelompok.

\section{HASIL DAN PEMBAHASAN}

Komposisi jenis makroalga

Hasil identifikasi makroalga yang ditemukan pada seluruh stasiun di perairan Desa Mantang Baru, terdiri dari 3 divisi, 3 kelas, 10 ordo, 14 famili, 14 genus, 15 spesies. Stasiun 2 (ekosistem padang lamun) memiliki jumlah individu tertinggi (282 ind) dari 12 spesies, diikuti oleh stasiun 1 (ekosistem karang) dijumpai 10 spesies (196 ind), dan stasiun 3 (yang berhadapan pada ekosistem mangrove) dijumpai 9 spesies (223 ind). Makroalga jenis $P$. Australis dan $S$. cristaefolium dijumpai pada semua stasiun pengamatan (Tabel 1).

Divisi Chlorophyta (alga hijau) merupakan kelompok yang paling banyak dijumpai di ekosistem lamun (59\%), sedangkan di ekosistem karang dan daerah yang berhadapan dengan mangrove, komposisi tertinggi dari divisi Phaeophyta (alga coklat) dengan komposisi masing-masing 69\% dan $44 \%$ (Gambar 3). Tingginya komposisi makroalga divisi Phaeophyta (alga coklat) pada ekosistem karang mengindikasikan bahwa ekosistem ini dapat menjadi tempat menempel yang cocok untuk makroalga tersebut. Hal ini didukung dengan tipe subtrat dominan pecahan karang, karang mati, dan berbatu. Kumalasari et al. (2018) bahwa divisi Phaeophyta (alga coklat) dari spesies S.cristaefolium ditemukan pada subtrat berbatu karena batu-batuan mampu melindungi hempasan arus yang kuat. Sedangkan Ira et al. (2018) juga mengatakan bahwa jenis makroalga dari $S$. cristaefolium sebagian besar ditemukan menempel pada rataan terumbu yang memiliki holdfast berbentuk cakram berguna untuk menempel kuat pada substrat.

Cholrophyta (alga hijau) terutama spesies H.macroloba paling banyak dijumpai di stasiun 2 (ekosistem lamun). Kondisi ini diduga disebabkan oleh tipe subtrat yang dominan dipenuhi oleh lumpur berpasir dan pasir sebagai tempat tumbuh yang baik untuk makroalga tersebut. Hal ini sesuai dengan pernyataan Ira $e t$ al. (2018) makroalga divisi Chlrophyta pada jenis H.macroloba dapat tumbuh pada berbagai subtrat karena memiliki kemampuan adaptasi yang tinggi dengan holdfast berupa kumpulan akar serabut dan mampu menarik subtrat kasar maupun partikel pasir. Sedangkan menurut Kadi dan Atmaja (1988), lokasi dengan habitat pasir kebanyakan ditumbuhi oleh makroalga Chlorophyta (alga hijau) dan makroalga Phaephyta (alga coklat). 


\section{Kerapatan jenis makroalga}

H. macroloba merupakan spesies yang memiliki kerapatan tertinggi, dijumpai pada stasiun 2 (37.300 ind $\mathrm{ha}^{-1}$ ), sedangkan $P$. autralis merupakan jenis yang memiliki kerapatan tertinggi di satsiun 1 dan 3, dengan kerapatan masing-masing yaitu 22.300 ind ha ${ }^{-1}$ dan 24.300 ind ha $\mathrm{h}^{-1}$ (Gambar 4).

Kerapatan jenis makroalga $P$. australis yang tinggi di ekosistem karang dan wilayah berhadapan dengan ekosistem mangrove disebabkan kemampuan bertahan pada subtrat yang keras, dibuktikan dengan tipe subtrat yang dominan berbatu sebagai tempat melekatnya makroalga. Hal tersebut sesuai dengan pernyataan Ira et al. (2018) bahwa tingginya makroalga dari genus Padina disebabkan daya adaptasi yang cukup tinggi terhadap ligkungan.

Kerapatan jenis $H$. macroloba yang tinggi di ekosistem lamun mengindikasikan ekosistem lamun merupakan habitat yang cocok untuk pertumbuhan jenis makroalga tersebut. Alga jeni ini dapat mengikat dengan kuat partikel-partikel pada subtrat tipe subtrat yang dominan lumpur pasir, sehingga dapat tumbuh dengan baik. Hal ini sesuai dengan pernyataan Arfah dan Patty (2014) bahwa pertumbuhan lamun yang mendominasi daerah tepi pantai merupakan habitat yang mendukung pertumbuhan makroalga dari genus Caulerpa, Halimeda, Amphiroa, dan Gracilaria.

Menuruta Ira (2018) perairan yang tenang justru tidak baik bagi habitat makroalga, karena akan menyebabkan akumulasi endapan lumpur sehingga menghambat pertumbuhan makroalga. Sunarernanda et al. (2014) menyatakan bahwa arus merupakan faktor pembatas dalam penyebaran spora, pelekatan, dan pertumbuhan rumput laut. Sedangkan menurut (Wulandari et al., 2015) arus membawa zat hara yang ada di perairan sehingga zat hara yang ada di perairan dapat tersebar dan gerakan air memengaruhi melekatnya spora pada makroalga.

\section{Indeks ekologi makroalga}

Indeks keanekaragaman makroalga di perairan Desa Mantang Baru, Kabupaten Bintan tergolong rendah di semua stasiun, indeks keseragaman tinggi, dan dominasi rendah (Gambar 5).

Nilai indeks keanekaragaman dari seluruh stasiun menunjukan pada kategori rendah, desebabkan oleh kondisi lingkungan yang kurang baik untuk jumlah jenis makroalga. Hal tersebut dibuktikan dengan nilai kadar nitrat dan fosfat yang cukup tinggi sehingga perairan tersebut menjadi tidak sesuai dengan baku mutu laut untuk biota.

Perbandingan hasil penelitian keanekaragaman jenis makroalga oleh Kadi (2005) di perairan Pulau Pangelap, Dedap, Abang Besar dan Abang Kecil, Kabupaten Bintan juga dalam kategori rendah. Hal ini dikarenakan disebabkan oleh kompleksitas habitat akibat kerusakan substrat yang disebabkan oleh proses sedimentasi di rataan terumbu yang berasal dari abrasi daratan/hutan pada waktu hujan atau gelombang tinggi. Arfah dan Patty (2014) mengatakan bahwa perairan yang mempunyai nilai keanekaragaman makroalga tinggi umumnya pada perairan dalam kondisi baik, sebaliknya kondisi perairan yang kurang baik akan menunjukkan keanekaragaman lebih rendah.

Tingginya nilai keseragaman dan rendahnya dominasi pada seluruh stasiun mengindikasikan bahwa tekanan ekologis lingkungan relatif rendah. Hal ini menyebabkan jumlah individu antara makroalga yang ditemukan tidak berbeda jauh. Masing-masing jenis makroalga memilikikemampuan adaptasi terhadap lingkungan (terutama perbedaan tipe substrat). Hal ini mengindikasikan bahwa makroalga memiliki kemampuan penempelan berbeda sesuai dengan tipe substratnya. 


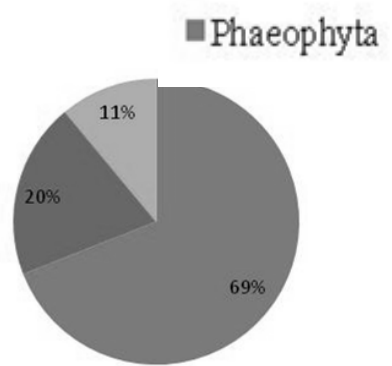

Stasiun 1

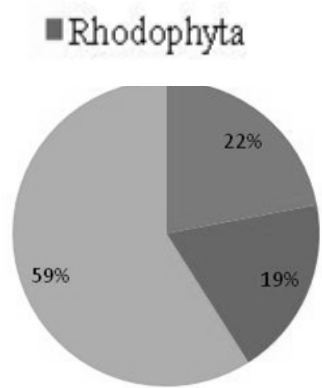

Stasiun 2
Chlorophyta

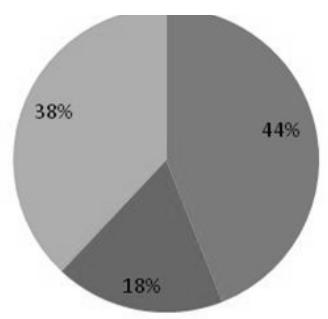

Stasiun 3

Gambar 3. Komposisi jenis makoalga berdasarkan divisi di perairan Desa Mantang Baru

Tabel 1. Komposisi Jenis Makroalga di perairan Desa Mantang Baru

\begin{tabular}{|c|c|c|c|c|c|}
\hline \multirow{2}{*}{ Divisi } & \multirow{2}{*}{ Genus } & \multirow{2}{*}{ Spesies } & \multicolumn{3}{|c|}{ Stasiun } \\
\hline & & & 1 & 2 & 3 \\
\hline \multirow[t]{6}{*}{ Chlorophyta } & Avrainvillea & A. erekta & - & + & + \\
\hline & Halimeda & H. macroloba & - & + & + \\
\hline & & H. opuntia & - & + & + \\
\hline & Chlorodesmis & C. fastiagiata & - & + & + \\
\hline & Anadyomene & A. wrightii & + & - & - \\
\hline & Neomeris & N. vanbosseae & + & - & - \\
\hline \multirow[t]{2}{*}{ Phaeophyta } & Padina & P. australis & + & + & + \\
\hline & Sargasum & S. cristaefolium & + & + & + \\
\hline \multirow[t]{7}{*}{ Rhodophyta } & Amphiroa & A. rigida & - & + & - \\
\hline & Cryptopleura & C. ramose & + & + & - \\
\hline & Acanthophora & A. spicifera & + & + & + \\
\hline & Chondrus & C. crispus & + & - & - \\
\hline & Gracilaria & G. salicornia & + & + & + \\
\hline & Liagora & L. ceranoides & + & + & + \\
\hline & Sarconema & S. scinaioides & + & + & - \\
\hline
\end{tabular}

Keterangan: dijumpai (+) dan tidak dijumpai (-)

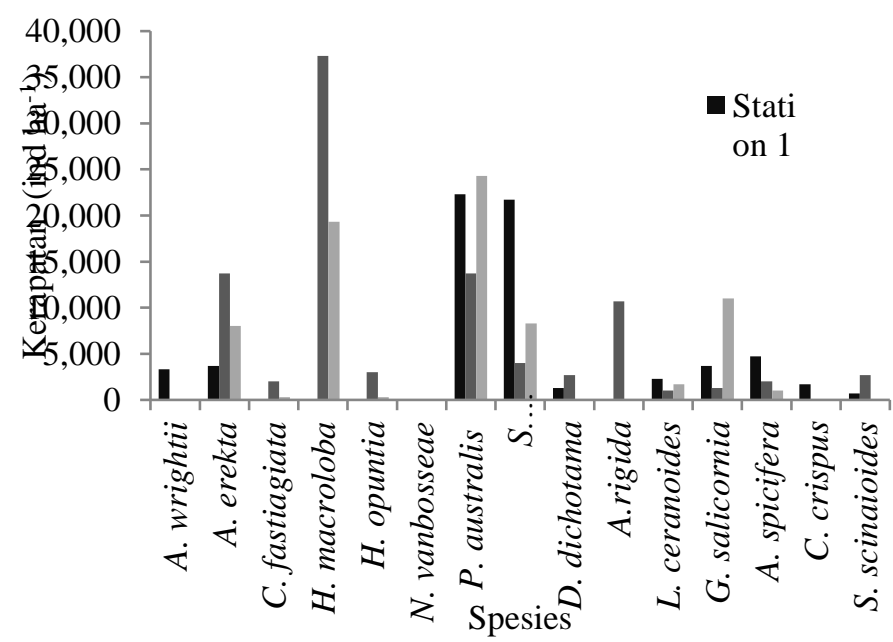

Gambar 4. Kerapatan jenis makroalga di perairan Desa Mantang Baru 


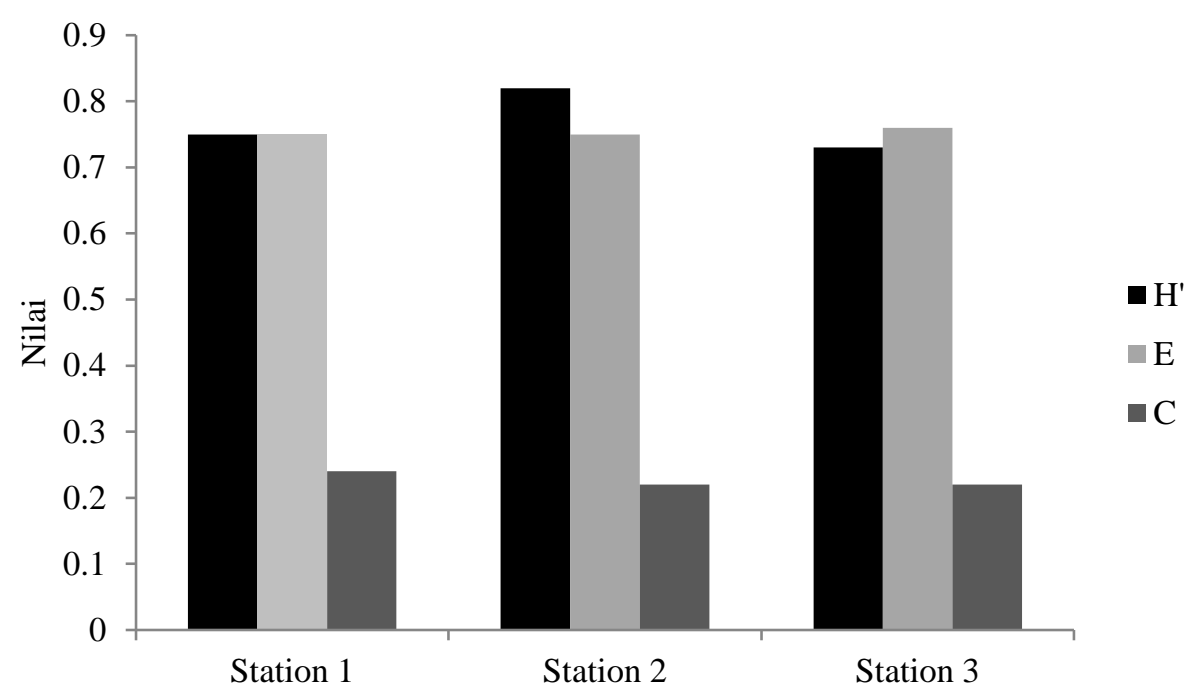

Gambar 5. Indeks ekologi makroalga di perairan Desa Mantang Baru

\section{Pola sebaran makroalga}

Nilai pola sebaran jenis makroalga pada stasiun 1, 2 dan 3 menunjukan kategori sebaran mengelompok (Tabel 2).

Nilai pola sebaran jenis makroalga pada stasiun 1, 2 dan 3 menunjukan kategori sebaran mengelompok. Hal tersebut disebabkan oleh kemampuan masing-masing jenis makroalga untuk memilih subtrat yang cocok untuk menempel pada daerah yang akan ditempati.

Rosdiana et al. (2017) menyatakan bahwa pola sebaran mengelompok disebabkan oleh faktor ekologi perairan yang dapat mengontrol keberadaan makroalga dan karakteristik biologis makroalga. Misalnya jenis Padina australis yang dapat bertahan hidup pada substrat berbatu karena memiliki holdfast rhizoid seperti cakram yang biasa digunakan untuk menempel pada pecahan karang mati. Sedangkan menurut Kadi (2005), kehadiran spesies makroalga di suatu wilayah ditentukan oleh faktor karakteristik lingkungan dan karakteristik makroalga itu sendiri. Kesesuaian antara kedua faktor tersebut akan menentukan pertumbuhan makroalga termasuk kemampuan menempel pada tahap awal pertumbuhannya.

\section{Parameter fisika dan kimia perairan}

Parameter fisika dan kimia perairan di Desa Mantang Baru secara unum memenuhi baku mutu peruntukan biota, kecuali parameter nitrat dan fosfat (Tabel 3).

Tabel 2. Pola sebaran jenis makroalga di perairan Desa Mantang Baru

\begin{tabular}{ccc}
\hline Stasiun & Morisita (Id) & Kategori \\
\hline 1 & 1,87 & Mengelompok \\
2 & 2,27 & Mengelompok \\
3 & 3,46 & Mengelompok \\
\hline
\end{tabular}

Tabel 3. Parameter fisika dan kimia di perairan Desa Mantang Baru

\begin{tabular}{lccccc}
\hline \multirow{2}{*}{ Parameter } & Satuan & \multicolumn{4}{c}{ Stasiun } \\
\cline { 3 - 5 } & & $\mathbf{1}$ & $\mathbf{2}$ & $\mathbf{3}$ & Baku Mutu* \\
\hline Suhu & ${ }^{\circ} \mathrm{C}$ & $30,5 \pm 0,1$ & $30,2 \pm 0,4$ & $30,4 \pm 0,0$ & $28-30$ \\
Kecepatan Arus & $\mathrm{m} \mathrm{s}^{-1}$ & $0,049 \pm 0,006$ & $0,040 \pm 0,006$ & $0,018 \pm 0,003$ & \\
Kedalaman & $\mathrm{cm}$ & $152 \pm 10,41$ & $142 \pm 10,41$ & $132 \pm 20,21$ & \\
Kecerahan & $\%$ & $100 \pm 0$ & $100 \pm 0$ & $100 \pm 0$ &
\end{tabular}




\begin{tabular}{lccccc} 
Salinitas & $\%$ & $30,3 \pm 0,56$ & $30,0 \pm 0,00$ & $30,3 \pm 0,58$ & $33-34$ \\
pH & & $7,74 \pm 0,21$ & $7,71 \pm 0,24$ & $8,01 \pm 0,13$ & $7-8,5$ \\
DO & $\mathrm{mg} \mathrm{L}^{-1}$ & $6,07 \pm 0,31$ & $6,63 \pm 0,31$ & $5,57 \pm 0,15$ & $>5$ \\
Nitrat & $\mathrm{mg} \mathrm{L}^{-1}$ & $2,07 \pm 0,21$ & $2,37 \pm 0,50$ & $2,63 \pm 0,50$ & 0,008 \\
Fosfat & $\mathrm{mg} \mathrm{L}^{-1}$ & $0,016 \pm 0,001$ & $0,018 \pm 0,005$ & $0,017 \pm 0,003$ & 0,015 \\
\hline
\end{tabular}

*Baku mutu berdasarkan KepMenLH No. 51 Tahun 2004

Nilai parameter suhu perairan Desa Mantang Baru relatif baik karena masih sesuai dengan baku mutu. Menurut KepMen-LH No 51 (2004) tentang baku mutu air laut untuk biota suhu berkisar antara $28-30{ }^{\circ} \mathrm{C}$. Ira (2018) mengatakan suhu perairan yang yang baik untuk pertumbuhan makroalga yaitu $30^{\circ} \mathrm{C}$. sedangkan menurut Luning (1990) bahwa suhu optimal untuk pertumbuhan makroalga di daerah tropis berkisar antara $15^{\circ} \mathrm{C}-30^{\circ} \mathrm{C}$. Batas maksimum untuk pertumbuhan alga hijau, coklat dan merah berkisar $34,5-37^{\circ} \mathrm{C}$ (Hutagalung, 1988).

Nilai parameter DO di perairan Desa Mantang Baru masih dikatakan baik karena sesuai dengan baku mutu peruntukan biota. Menurut KepMen-LH No. 51 (2004) tentang baku mutu air laut untuk biota, DO berkisar antara $>5 \mathrm{mg} / \mathrm{L}$. Salmin (2005) mengatakan bahwa Oksigen sangat dibutuhkan oleh semua jasad hidup untuk pernapasan dan proses metabolisme. Dalam perairan oksigen berperan dalam proses oksidasi den reduksibahan kimia menjadi senyawa yang lebih sederhana sebagai nutrien yang sangat dibutuhkan organisme perairan. Sumber utama oksigen di perairan berasal dari prosesdifusi udara bebas dan hasil proses fotosintesis.

Nilai parameter $\mathrm{pH}$ tertinggi pada stasiun 3 yang berhadapan pada ekosistem mangrove, dan yang terendah pada stasiun 2 ekosistem lamun. pH perairan Desa Mantang Baru masih cukup baik karena masih sesuai dengan baku mutu, seperti yang terlampir pada KepMen-LH No 51 (2004) tentang baku mutu air laut untuk biota dengan baku mutu $7-8,5$.

Menurut Atmadja et al (1996), pergerakan air yang baik untuk pertumbuhan makroalga adalah $0,2-0,5 \mathrm{~ms}^{-1}$. Sedangkan Widyastuti (2008) menyatakan bahwa kisaran nilai kecepatan arus yang baik untuk pertumbuhan makroalga yaitu $0,10-0,50 \mathrm{~ms}^{-1}$. Kecepatan arus mengakibatkan zat hara yang ada di perairan dibawa arus sehingga zat hara di perairan dapat tersebar dan gerakan air memengaruhi melekatnya makroalga pada subtrat (Wulandari, 2015).
Nilai parameter kecerahan dan kedalaman pada seluruh stasiun sangat mendukung untuk pertumbuhan makroalga karena dapat membantu makroalga dalam proses potosintesis. Menurut Ira et al. (2018), kecerahan dan kedalaman perairan dapat memengaruhi kepadatan dan distribusi makroalga yang hidup di dasar laut banyak terdapat pada zona pasang surut sedalam cahaya matahari dapat tembus.

Luning (1990) menjelaskan bahwa makroalga umumnya hidup di laut dengan kisaran salinitas antara 30-32 \%o, namun banyak jenis makroalga hidup pada kisaran salinitas yang lebih besar. Salinitas berperan penting dalam kehidupan makroalga, salinitas yang terlalu tinggi atau terlalu rendah akan menyebabkan gangguan pada proses fisiologis (Arfah dan Patty 2016).

Nilai parameter fosfat di perairan Desa Mantang Baru tidak memenuhi baku mutu bagi kehidupan biota laut menurut KepMen-LH No 51 (2004). Arfah dan Patty (20114) menjelaskan bahwa fosfat merupakan salah satu zat hara yang dibutuhkan dan mempunyai pengaruh terhadap pertumbuhan dan perkembangan hidup organisme di laut.

Konsentrasi nitrat dan fosfat di suatu perairan merupakan salah satu indikator penentu kesuburan suatu perairan. Nitrat memiliki peranan yang cukup besar terhadap pertumbuhan makroalga di perairan, besarnya suplai nitrat ke perairan menyebabkan pertumbuhan alga dan makroalga yang lebih (Rani et al., 2013).

\section{KESIMPULAN}

Divisi Chlorophyta (alga hijau) merupakan kelompok yang paling banyak dijumpai di ekosistem lamun (59\%) di perairan Desa Mantang Baru, Kabupaten Bintan, sedangkan di ekosistem karang dan daerah yang berhadapan dengan mangrove, komposisi tertinggi dari divisi Phaeophyta (alga coklat) dengan komposisi masing-masing 69\% dan 44\%. Pola sebaran pada jenis makroalga di perairan Desa Mantang Baru pada setiap 
stasiun termasuk kategori mengelompok dengan kisaran nilai 1,87-3,46. Parameter fisika dan kimia perairan di Desa Mantang Baru secara unum memenuhi baku mutu peruntukan biota, kecuali parameter nitrat dan fosfat.

\section{DAFTAR PUSTAKA}

(APHA) American Public Health Association. 2012. Standard Methods for the Examination of Water and Wastewater, $22^{\text {nd }}$ Edition. Editor E.W., Rice R.B., Baird A.D., Eaton L.S. (eds). Clesceri.American Public Health Association, Virginia.

Arfah, H., dan Patty, S.I. 2014. Keanekaragaman dan Biomassa Makro Algae di Perairan Teluk Kotania, Seram Barat. Jurnal Ilmiah Platax. 2(2):63-73.

Atmadja, W.S., Kadi, A.,Sulistijo., Radiamanias. 1996. Pengenalan JenisJenis Rumput Laut di Indonesia. Puslitbang Oseanografi. LIPI. Jakarta. 191.

Brower, J. E., J. H. Zar and C. von Ende. 1990. General Ecology. Field and Laboratory Methods.Wm. C. Brown Company Publisher, Dubuque, Iowa.

English, S., Wilkinson, C., dan Baker, V., 1997. Survey Manual for Tropical Marine Resources, $2^{\text {nd }}$ Edition. Townsville: Australian Institute of Marine Science.

Fachrul.2007. Metode Sampling Bioekologi. PT Bumi Aksara. Jakarta.

Hambali, M., Jaya, Y.V., Irawan, H. 2012. Aplikasi SIG Untuk Kesesuaian Kawasan Budidaya Rumput Laut Eucheuma cottonii dengan Metode Lepas Dasar di Pulau Mantang, Kecamatan Mantang, Kabupaten Bintan. Repositiry UMRAH. http://jurnal.umrah.ac.id/?p=1171

Hutagalung, H.P., 1988. Pengaruh Suhu Air Terhadap Kehidupan Organisme Laut. Jurnal Oseana. 13(4): 153-164.

Ira. 2018. Struktur Komunitas Makroalga di Perairan Desa Mata Sulawesi Tenggara. Jurnal Biologi Tropis. 18(1): 41-56.

Ira, Ramadani, Irawati, N. 2018. Komposisi Jenis Makroalga di Perairan Pulau Hari Sulawesi Tenggara. Biologi Tropis. 18(2): 141-158.

Kadi, A. 2015.Stok Rumput Laut Alami di Perairan Teluk Prigi Trenggalek JawaTimur. Jurnal ilmiah Biosfera. 32(3): 176184.

Kadi, A., Atmadja, W,S. 1988. Rumput Laut (Algae) Jenis, Reproduksi, Produksi,
Budidaya dan Pasca Panen. Pusat penelitian dan Pengembangan Oseanologi. Lembaga Ilmu Pengetahuan Indonesia. Jakarta. 71.

Keputusan Menteri Negara Lingkungan Hidup (KEPMEN-LH) No 50 th 2004 Tentang Baku Mutu Air Laut. Lampiran III

Krebs, C.J. 2014. Species Diversity Measures. Addison Wesley Longman, Inc. New York. Version 5.

Kumalasari, Sulistiyowati, H., Styati, D. 2018. Komposisi Jenis Alga Makrobentik Divisi Phaeophyta di Zona Intertidal Pantai Pancur Taman Nasional Alas Purwo. Berkala Sainstek. 6(1): 28-30.

Luning, K. 1990. Seaweeds, Their Environment, Biogeography And Ecophysiology. John Wiley and Sons. New York. 544 Pages.

Meriam, W.P., Kepel, R.C., Lumingas, L. J. 2016. Inventarisasi Makroalga di Perairan Pesisir Pulau Manteghe Kecamatan Wori, Kabupaten Minahasa Utara, Provinsi Sulawesi Utara. Jurnal Ilmiah Platax. 4(2) : 84-108.

Rani, C., Nessa, M.N., Jompa, J., Toaha, S., Faizal, A., 2013. Dinamika SpasioTemporal dan keterkaitan Nutrien, Makroalga dan Ikan karang Herbivora di Kepulauan Spermonde Sulawesi Selatan. Seminar Nasional tahunan X. 2(1): 1-18.

Rosdiana, Nurgayah., W., Ira. 2017. Struktur Komunitas Makroalga di Perairan Waworaha Kecamatan Soropia. Jurnal Sapa Laut (Jurnal Ilmu Kelautan). 2(3): 69-77.

Salmin. 2005. Oksigen Terlarut (DO) dan Kebutuhan Oksigen Biologi (BOD) Sebagai Salah Satu Indikator untuk Menentukan Kualitas Perairan. Oseana. 30(3): 21-26.

Sunarenanda, Y.P., Ruswahyuni., Suryanti. 2014. Hubungan Kerapatan Rumput Laut Dengan Kelimpahan Epifauna pada Subtrat Berbeda di Pantai Teluk Awur Jepara. Management of Aquatic Resources Journal. 3(3): 43-51.

Widyastuti, S., 2008.Pengolahan Pasca Panen Alga Merah Strain Lokal Lombok Menjadi Agar-agar Menggunakan Dua Metode Ekstraksi. Jurnal Penelitian UNRAM. 14(2): 7-63.

Wulandari, S.R., Hutabarat, S., Ruswahyuni.2015. Pengaruh Arus dan Substrat Terhadap Distribusi Kerapatan 
KOMPOSISI DAN POLA SEBARAN MAKROALGA DI PERAIRAN DESA MANTANG BARU, KABUPATEN BINTAN, KEPULAUAN RIAU

Rumput Laut di Perairan Pulau Panjang Sebelah Barat dan Selatan. Diponegoro Journal of Maquares. 4(3): 91-98. 